\title{
Reflections on a school for all: perceptions of families and teachers regarding the culture, policy, and practice of inclusion in Galicia
}

\section{María Fiuza-Asorey}

Universidad de Santiago de Compostela, España

Email: maría.fiuzadusc.es

ORCID: http://orcid.org/0000-0003-4684-3188

\section{Luisa Losada-Puente}

Universidade da Coruña, España

Email: luisa.losada@udc.es

ORCID: http://orcid.org/0000-0003-2300-9537

\author{
Manoel Baña-Castro \\ Universidad de Santiago de Compostela, España \\ Email: manoel.banadusc.es \\ ORCID: http://orcid.org/0000-0002-4410-3082
}

\begin{abstract}
This paper examines, for the first time in Galicia (Spain), the culture, policy and practice of teachers and families in six primary schools. The aim was to understand their reality from an inclusive perspective and, subsequently, being able to establish some course of action for improvement. Within the framework of participatory, descriptive, exploratory, and explanatory research, an adaptation of the Index for Inclusion (Booth \& Ainscow, 2015) was applied to a sample of 158 families and 85 teachers. The results showed that both groups advocated for an inclusive education, but there were some discrepancies between the intentions and the reality of schools. Differences between culture and practice were probably the element that most brought those contradictions to light. So far, some steps have been taken towards educational inclusion, generating a debate on how to improve it. But it has not included a joint analysis of the voices of all families and teachers, key agents to promote a school for all. What has been found have been isolated initiatives, promoted by education administrators, teachers, or families of students with special educational needs. Hence the need to stimulate the joint reflection on how to move toward total inclusion.
\end{abstract}

Key words: Index for Inclusion, school inclusion, primary education, school improvement, teacher-parent interaction.

\section{Reflexiones acerca de una escuela para todos: percepciones de familias y maestros respecto a la cultura, po- lítica y práctica de inclusión en Galicia}

\section{RESUMEN}

Este trabajo examina, por primera vez en Galicia (España), las percepciones acerca de la cultura, política y práctica del profesorado y familias de seis escuelas primarias. El objetivo fue comprender su realidad desde una perspectiva inclusiva para, posteriormente, proponer acciones de mejora. Bajo una modalidad de investigación participativa, descriptiva, exploratoria y explicativa, se aplicó una adaptación al español del Index for Inclusion (Booth \& Ainscow, 2015) a una muestra de 158 familias y 85 docentes. Los resultados mostraron que ambos grupos abogaron por una educación inclusiva, pero existieron discrepancias entre las intenciones y la realidad de las escuelas. Las diferencias entre cultura y práctica fueron, probablemente, el elemento que más sacó a la luz esas contradicciones. Hasta ahora se han dado algunos pasos hacia la inclusión educativa, generando un debate sobre cómo mejorarla. Pero no se ha incluido un análisis conjunto de las voces de todas las familias y docentes, agentes clave para impulsar una escuela para todos. Lo que se han encontrado han sido iniciativas aisladas, promovidas por administradores educativos, por docentes o por familias de alumnos con necesidades específicas de apoyo educativo. De ahí la necesidad de estimular la reflexión conjunta sobre cómo avanzar hacia la inclusión total.

Palabras clave: Index for Inclusion, inclusión educativa, educación primaria, mejora escolar, interacción docente-familia.

ISSN: 0210-2773

DOI: https://doi.org/10.17811/rifie.50.1.2021.525-534 


\section{Introduction}

As many voices have pointed out, the debate on the concept of inclusion in education is still open across the world (Ainscow \& Messiou, 2018; Cardona-Molto, Ticha \& Abery, 2020; Cenci, Ferreira, Fuhro, Damiani \& Engeström, 2020; Paseka \& Schwab, 2020). It has led to diverse school realities that range from segregation with different levels of participation in the ordinary classroom to supportive schools whose doors are open to all. Adhering to the latter idea leads to seeing beyond the restricted vision of a school that simply incorporates students with various disabilities in the classrooms. On the contrary, it turns the gaze to overcoming barriers limiting learning and participation of all, and to discovering the systems of support that open the path to total inclusion (Materechera, 2020; Soldevilla, Naranjo, \& Muntaner, 2017).

Schools represent a group of people interacting (Mateus, Vallejo, Obando, \& Fonseca, 2017), living with the difference and learning to learn from the difference (Messiou \& Ainscow, 2020). That is how pigeonholing students is overcome; the attention is no longer focused exclusively on that, and the marginalization of those students who don't fit into any pre-fixed category is avoided (Ainscow \& Messiou, 2018).

This research investigates, for the first time in Galicia (Spain), the strengths and the weaknesses of six primary schools through the voices of teachers and families (in a previous study, the students' voice was analyzed). An adaptation of the Index for Inclusion (Booth \& Ainscow, 2015) has been used, as it is a global reference in the field of attention to diversity. It aids to explore how schools address diversity through their culture, policy, and practices (Crisol, 2019) and to identify the boundaries of access to and participation in learning, the support needed to develop an inclusive education, and could serve to implement measures of inclusive development.

1.1. The Spanish reality in inclusion: the difficult task of reconciling neoliberalism and inclusion

The rights of people who need special support are established by the Spanish Constitution (art. 27) and some specific regulations such as the General Law of Rights of people with disabilities and their social inclusion. Besides, the educational laws use the concept of specific educational support needs to refer to those students who need and receive an educative attention different from the ordinary, owing to special educational needs, specific learning difficulties, ADHD, high intellectual ability, late incorporation into the educational system, or personal or academic conditions. The educational counselling services or the competent personnel are responsible for considering the students as such (Ministerio de Educación y Formación Profesional, 2019). Each Spanish Autonomous Communities establishes their way of implementing the right to education, and the material and human resources invested in the inclusive process. Consequently, inclusive education still largely depends on a given individual's criterion to decide who receives a segregated or in an ordinary classroom education.

Each Spanish Autonomous Communities establishes their way of implementing the right to education, and the material and human resources invested on it. Consequently, the outlook on inclusive education is still very restricted, as it largely depends on a given individual's criterion, at a given point in time, to decide who receives what type of education (segregated or in an ordinary classroom). Consequently, inclusive education still largely depends on a given individual's criterion, at a given point in time, to decide who receives a segregated or in an ordinary classroom education.
In a democratic society, the schools must contemplate differences as a value inherent to the teaching and learning processes (Arnaiz \& Azorín, 2014). The rise of neoliberalism in many countries, to which Spain is no exception, has led to an education headed off towards standardization and comparison among schools, with achievement being the top priority (Hedegaard-Soerensen \& Grumloese, 2020). Despite inclusion being present in all political agendas on an international scale (Azorín \& Ainscow, 2020; Ainscow \& Messiou, 2018), terms such as disorders or Special Educational Needs are still in use in scholar language (Brausteiner \& Mariano-Lapidus, 2014), even though to promote inclusive development, inclusive language is required (Nes, 2009).

1.2. When one door closes, another one opens: obstacles and support on the road to change

Those words illustrate the idea that, in spite of neoliberalism and the obstacles on the road to total inclusion, a change is possible. Building up the bases of educational quality implies transforming the educative systems with attention to their culture, policy, and practice (Crisol, 2019). Each school presents a different reality and setting up an inclusive culture requires identifying the obstacles, clearly context dependent, to the students' learning and participation (Arnaiz \& Azorín, 2014), and the type of support that will help them overcome it. Senge (1989) refers to it as levers of change or actions aimed at changing the behavior of an organization or the individuals within it.

In this sense, families must be positioned as "an equal member of the educational community, a resource and support for teachers and the school" (Simón \& Barrios, 2019, p. 53), and maintain a relationship and continuous collaborative work with the school, to achieve the shared goal of equal opportunities (ColletSabé, 2020). However, contacts between both institutions are usually limited to the management and governance of the school, through the participation of families in school boards and parents' associations (Collet-Sabé et al, 2014; Egido \& Bertrán, 2016). The search for co-responsibility formulas is an essential requirement to move towards inclusive education, but reality shows that they continue to work separately in the education of students (Valanzuela \& Sales, 2016).

Gaining positive outcomes for all students means that adults' behavior must change as a consequence of challenging their way of thinking, stimulating their social learning processes and, in turn, motivating new ways of behavior (Ainscow, 2002; Ainscow \& Messiou, 2018). So that, the Index for Inclusion is a good tool to achieve a fruitful interaction of the entire educational community.

This study aims to explore the potentialities and barriers in the inclusive process in terms of culture, policy, and practice in primary education, through the perceptions of families and teachers in Galicia (Spain). Specifically, this paper:

- Describes the perceptions on inclusive culture, policy and practice of the families and teachers from six Galician schools.

- Checks for differences in their perception of the inclusive process according to some sociodemographic variables (gender, age, grade attended, grade taught, presence of any learning difficulties, teaching function at the school).

- Analyzes the relationship between families' and teachers' perceptions on the inclusion at school.

\section{Method}

A collaborative inquiry was carried out. The focus was not only on obtaining research data, but also on supporting the partic- 
ipating schools and teachers in their self-improvement processes. The four principles formulated by Ainscow (2002) were adopted: (a) the process assumed a direct aid to the ones involved, both in the analysis and the assessment of the barriers to inclusion at their schools; (b) the work was conducted in a rigorous and reliable way; (c) the aim is to contribute to generalization of inclusive policies and practices; and (d) the presentation of the outcomes stimulates the enrichment among researchers.

The design was descriptive and exploratory, to inquire about the perceptions of families and teachers in terms of inclusive culture, policy, and practice in schools. Also, an explanatory design was conducted to study the possible motivations behind those evaluations (Hernández, Fernández, Baptista, Méndez \& Mendoza, 2015).

\subsection{Participants and context}

An intentional non-probability convenience sample consisting of 158 families and 85 teachers from Galician primary education schools was used. All data were collected in public centers, of which two were urban, two semi-urban, and two rural/fishing (see figure 1).

In the families group there were 91 mothers (57.6\%) and $67 \mathrm{fa}-$ thers $(42.4 \%)$, including $21.5 \%(n=40)$ under the age of $40,53.2 \%$ $(n=84)$ between $30-50$ years old, and $25.3 \%(n=40)$ older than 50. Furthermore, $58.9 \%(n=93)$ had basic studies, 38.6\% $(n=61)$ secondary studies, $2.5 \%(n=4)$ vocational training or, with the same percentage, university studies. Their children were studying in 1st grade $(\mathrm{n}=30,19.0 \%)$, 2nd $(\mathrm{n}=37,23.4 \%)$, 3rd $(\mathrm{n}=37,23.4 \%)$, 4 th $(n=11,7 \%), 5$ th $(n=15,9.5 \%)$ and 6 th grade $(n=28,17.7 \%)$. Some families reported learning difficulties in their children (n $=56,35.4 \%$ ).

As for the teachers, the sample was represented by 42 men (49.4\%) and 43 women (50.6\%), aged 29-39 $(\mathrm{n}=31,36.5 \%), 40-50$ $(n=26,30.6 \%)$ and over $50(n=28,32.9 \%) .74 .1 \%$ had a degree in Primary Education $(n=63)$, including $7.1 \%(n=6)$ who also specialized in areas such as English and Physical Education, and $18.8 \%$ in special education $(n=16)$. Their teaching had spanned from 1 st grade to 5 th grade, with a greater presence in the lower courses; namely: 1 st grade $(\mathrm{n}=21,24.7 \%), 2 \mathrm{nd}(\mathrm{n}=27,31.8 \%), 3 \mathrm{rd}$ $(\mathrm{n}=19,22.4 \%), 4$ th $(\mathrm{n}=11,12.9 \%)$ and 5 th $(\mathrm{n}=7,8.2 \%)$.

\subsection{Instrument}

The third version of the Index for Inclusion (3rd Booth \& Ainscow, 2015) was used to collect the data. It assesses, on a 4-point Likert scale, the agreement or disagreement of teachers and families on, respectively, 37 and 27 items referring to:

a) Creating inclusive cultures: with two sections:

- Building a community: better outcomes are accepted, supported, and encouraged for all its members.

- Establishing values: shared by all members of the community, involving them in the processes of participation and collaboration.

b) Producing inclusive policies: with two sections:

- Developing the school for all: facilitating the active participation.

- Organizing support for diversity: increasing the capacity of the schools to give a response to the students' diversity through internal policies and management processes.

c) Developing inclusive practices: refer to two aspects:

- Constructing curricula for all: material and personal resources useful to support the students' learning and participation.

- Orchestrating learning: implementation of learning so that students are encouraged to become involved in all experiences inside and outside of school.

The Index aims to serve schools as a tool for self-analysis and self-assessment of their inclusive practices. Recent studies, using the Spanish version of the instrument, allow to report on its psychometric properties. Castillo, Miranda, Norambuena and Galloso (2020) obtained results regarding reliability that exceed those of the present study, both in teachers $(\alpha=.904)$ and families $(\alpha$ = .931); and Fernández-Archilla et al. (2020) confirm the factorial structure of the Spanish version, as well as an internal reliability of $\alpha=.84$ (sample of students). In this study, the analysis of its psychometric properties showed an internal consistency from

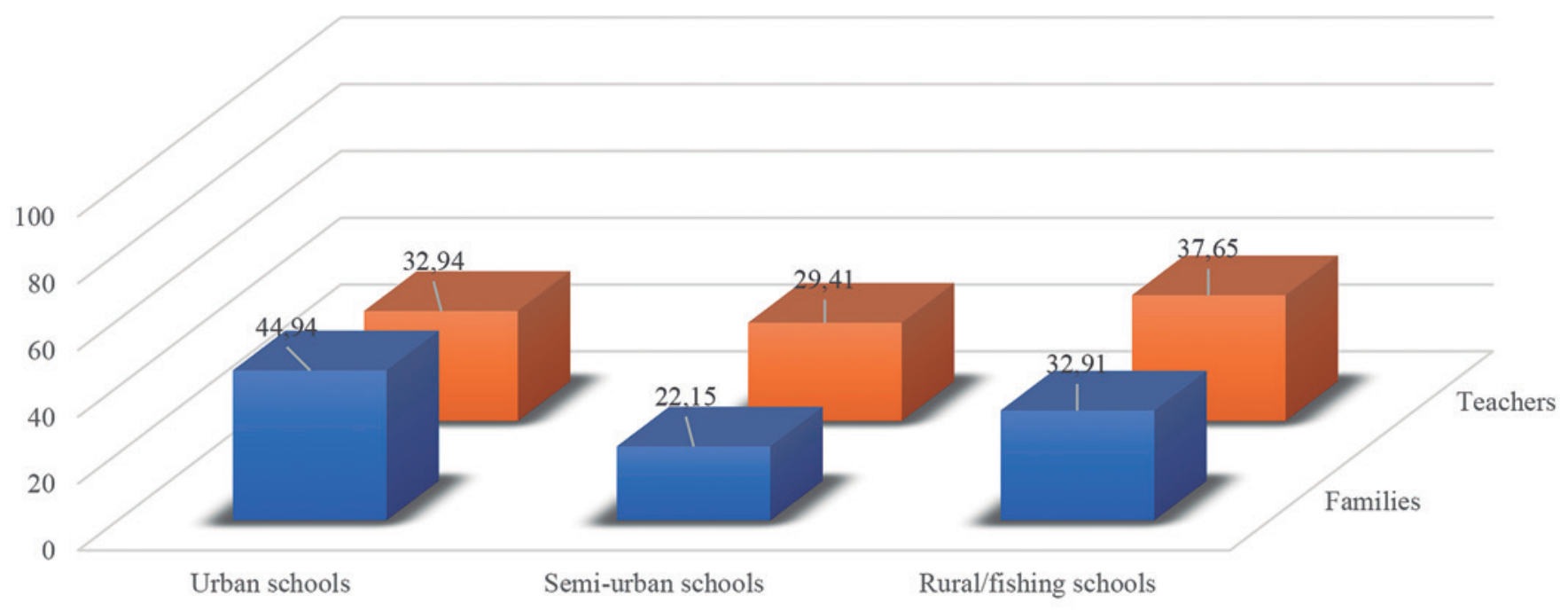

-Families $\quad$ Teachers

Figure 1. Distribution of the sample according to the type of school. 
Table 1.

Distribution of the results and internal consistency of the Index

\begin{tabular}{|c|c|c|c|c|c|c|c|c|c|c|}
\hline \multirow[b]{2}{*}{ Dimensions } & \multicolumn{5}{|c|}{ Families } & \multicolumn{5}{|c|}{ Teachers } \\
\hline & No. items & Mean & SD & $\alpha$ & $\begin{array}{c}\alpha \text { standard } \\
\text { elements }\end{array}$ & No. items & Mean & SD & $\alpha$ & $\begin{array}{c}\alpha \text { standard } \\
\text { elements }\end{array}$ \\
\hline Culture & 9 & 2.37 & 0.59 & .741 & .741 & 12 & 2.35 & 0.69 & .896 & .89 \\
\hline Policies & 10 & 2.46 & 0.70 & .873 & .874 & 16 & 2.46 & 0.64 & .914 & .909 \\
\hline Practice & 8 & 2.23 & 0.55 & .653 & .648 & 9 & 2.41 & 0.69 & .886 & .888 \\
\hline Total & 27 & 2.36 & 0.47 & .858 & .859 & 37 & 3.89 & 0.65 & .963 & .961 \\
\hline
\end{tabular}

good to excellent, both for the families and the teachers, and for the global Index and its dimensions (see table 1).

\subsection{Data collection and analysis}

The participation of all families and teachers was requested. They were informed of the possibility of participating voluntarily and anonymously. The access to the sample was made through the management team of the participating six participating centers. Through this, families got a letter containing the questionnaire and a document explaining the motives of the study and the researchers' commitment to confidentiality. Those who accepted sent the responses back to the school, where were collected by the researchers. Teachers were not only requested to complete the questionnaire, but also to aid analyses and assess the barriers to inclusion at their centers. It is worth noticing how the functional, operative, and collaborative nature of this process was not only aimed at data collection, but also beneficial to the participants themselves in the search for inclusion and educational quality at the educational center.
A period of one week was established for the completion of the questionnaires, so that they could be filled in in a calm and quiet manner for the sake of obtaining truthful and reliable information. Once the information had been collected, the questionnaires that were not completely filled out or were blank were eliminated ( $n=7$ of families and $n=3$ of teachers).

Data analysis was supported by using the Statistic Package for Social Sciences (IBM SPSS 26). First, a reliability analysis was conducted, as presented in table 1. Secondly, through descriptive and inferential analyses the dimensions and indicators (or sub-dimensions) were explored, considering a Confidence Level of 95\% $(p<.05)$. The assumptions of normality in most variables (K-S $p<$ $.05)$ and homoscedasticity (Leven's statistic: $p<.05$ ) were checked and, consequently, parametric statistics were picked out. The following tests were used: Student's T-test, ANOVA and Pearson Correlation Coefficient. It was necessary to incorporate non-parametric analysis (the Kruskal-Wallis $\mathrm{H}$ test and the Mann-Whitney U test) to study the teachers' function variable, due to the absence

Table 2.

Descriptive statistics: central tendency and dispersion values

\begin{tabular}{|c|c|c|c|c|c|c|c|c|c|c|}
\hline & \multicolumn{2}{|c|}{ Families } & \multicolumn{2}{|c|}{ Teachers } & \multicolumn{3}{|c|}{ Families (Grade) } & \multicolumn{3}{|c|}{ Teachers (Grade) } \\
\hline & Man & Woman & Man & Woman & $1-2$ & $3-4$ & $5-6$ & $1-2$ & $3-4$ & 5 \\
\hline Culture & $\begin{array}{l}2.77^{*} \\
(0.72)\end{array}$ & $\begin{array}{c}2.58 \\
(0.60)\end{array}$ & $\begin{array}{l}2.73^{* *} \\
(0.69)\end{array}$ & $\begin{array}{c}2.19 \\
(0.46)\end{array}$ & $\begin{array}{l}2.75^{*} \\
(0.71)\end{array}$ & $\begin{array}{c}2.27 \\
(0.65)\end{array}$ & $\begin{array}{c}2.24 \\
(0.57)\end{array}$ & $\begin{array}{l}2.59^{*} \\
(0.66)\end{array}$ & $\begin{array}{c}2.11 \\
(0.46)\end{array}$ & $\begin{array}{l}3.04^{*} \\
(0.44)\end{array}$ \\
\hline A1 & $\begin{array}{l}2.86^{*} \\
(0.83)\end{array}$ & $\begin{array}{c}2.56 \\
(0.73)\end{array}$ & $\begin{array}{l}2.76^{* *} \\
(0.85)\end{array}$ & $\begin{array}{c}2.05 \\
(0.56)\end{array}$ & $\begin{array}{l}2.78^{* *} \\
(0.85)\end{array}$ & $\begin{array}{c}2.15 \\
(0.80)\end{array}$ & $\begin{array}{c}2.19 \\
(0.72)\end{array}$ & $\begin{array}{l}2.53^{*} \\
(0.84)\end{array}$ & $\begin{array}{c}2.01 \\
(0.56)\end{array}$ & $\begin{array}{l}3.17^{*} \\
(0.68)\end{array}$ \\
\hline A2 & $\begin{array}{c}2.71 \\
(0.74)\end{array}$ & $\begin{array}{c}2.59 \\
(0.81)\end{array}$ & $\begin{array}{l}2.69^{*} \\
(0.58)\end{array}$ & $\begin{array}{c}2.33 \\
(0.43)\end{array}$ & $\begin{array}{l}2.73^{*} \\
(0.70)\end{array}$ & $\begin{array}{c}2.35 \\
(0.67)\end{array}$ & $\begin{array}{c}2.27 \\
(0.59)\end{array}$ & $\begin{array}{l}2.64^{*} \\
(0.54)\end{array}$ & $\begin{array}{c}2.21 \\
(0.44)\end{array}$ & $\begin{array}{l}2.91^{*} \\
(0.23)\end{array}$ \\
\hline Policy & $\begin{array}{l}2.67^{*} \\
(0.75)\end{array}$ & $\begin{array}{c}2.27 \\
(0.52)\end{array}$ & $\begin{array}{l}2.67^{* *} \\
(0.69)\end{array}$ & $\begin{array}{c}2.03 \\
(0.53)\end{array}$ & $\begin{array}{l}2.63^{* *} \\
(0.58)\end{array}$ & $\begin{array}{l}2.39^{* *} \\
(0.45)\end{array}$ & $\begin{array}{c}1.95 \\
(0.50)\end{array}$ & $\begin{array}{l}2.47^{*} \\
(0.68)\end{array}$ & $\begin{array}{c}2.01 \\
(0.54)\end{array}$ & $\begin{array}{l}2.94^{*} \\
(0.70)\end{array}$ \\
\hline B1 & $\begin{array}{c}2.53 \\
(0.85)\end{array}$ & $\begin{array}{c}2.21 \\
(0.58)\end{array}$ & $\begin{array}{l}2.83^{* *} \\
(0.92)\end{array}$ & $\begin{array}{c}2.03 \\
(0.62)\end{array}$ & $\begin{array}{l}2.60^{* *} \\
(0.72)\end{array}$ & $\begin{array}{l}2.35^{* *} \\
(0.50)\end{array}$ & $\begin{array}{c}1.93 \\
(0.53)\end{array}$ & $\begin{array}{l}2.59^{*} \\
(0.87)\end{array}$ & $\begin{array}{c}2.00 \\
(0.68)\end{array}$ & $\begin{array}{l}3.13^{*} \\
(0.93)\end{array}$ \\
\hline B2 & $\begin{array}{l}2.61^{*} \\
(0.80)\end{array}$ & $\begin{array}{c}2.34 \\
(0.67)\end{array}$ & $\begin{array}{l}2.50^{* *} \\
(0.54)\end{array}$ & $\begin{array}{c}2.04 \\
(0.51)\end{array}$ & $\begin{array}{l}2.66^{* *} \\
(0.71)\end{array}$ & $\begin{array}{l}2.44^{* *} \\
(0.72)\end{array}$ & $\begin{array}{c}1.98 \\
(0.69)\end{array}$ & $\begin{array}{l}2.35^{*} \\
(0.57)\end{array}$ & $\begin{array}{c}2.01 \\
(0.47)\end{array}$ & $\begin{array}{l}2.75^{*} \\
(0.55)\end{array}$ \\
\hline Practice & $\begin{array}{c}2.06 \\
(0.51)\end{array}$ & $\begin{array}{c}2.37 \\
(0.55)\end{array}$ & $\begin{array}{l}2.68^{* *} \\
(0.73)\end{array}$ & $\begin{array}{c}2.15 \\
(0.54)\end{array}$ & $\begin{array}{c}2.26 \\
(0.53)\end{array}$ & $\begin{array}{c}2.24 \\
(0.53)\end{array}$ & $\begin{array}{c}2.16 \\
(0.60)\end{array}$ & $\begin{array}{l}2.58^{*} \\
(0.70)\end{array}$ & $\begin{array}{c}2.11 \\
(0.59)\end{array}$ & $\begin{array}{c}2.52 \\
(0.69)\end{array}$ \\
\hline $\mathrm{C} 1$ & $\begin{array}{c}2.09 \\
(0.60)\end{array}$ & $\begin{array}{l}2.47^{*} \\
(0.62)\end{array}$ & $\begin{array}{l}2.59^{* *} \\
(0.74)\end{array}$ & $\begin{array}{c}2.30 \\
(0.50)\end{array}$ & $\begin{array}{c}2.33 \\
(0.72)\end{array}$ & $\begin{array}{c}2.24 \\
(0.68)\end{array}$ & $\begin{array}{c}2.27 \\
(0.67)\end{array}$ & $\begin{array}{l}2.58^{*} \\
(0.64)\end{array}$ & $\begin{array}{c}2.23 \\
(0.62)\end{array}$ & $\begin{array}{c}2.40 \\
(0.58)\end{array}$ \\
\hline $\mathrm{C} 2$ & $\begin{array}{c}2.03 \\
(0.63)\end{array}$ & $\begin{array}{c}2.28 \\
(0.61)\end{array}$ & $\begin{array}{l}2.79^{*} \\
(0.92)\end{array}$ & $\begin{array}{c}1.97 \\
(0.74)\end{array}$ & $\begin{array}{c}2.20 \\
(0.65)\end{array}$ & $\begin{array}{c}2.25 \\
(0.66)\end{array}$ & $\begin{array}{c}2.05 \\
(0.68)\end{array}$ & $\begin{array}{l}2.58^{*} \\
(0.97)\end{array}$ & $\begin{array}{c}1.98 \\
(0.73)\end{array}$ & $\begin{array}{c}2.68 \\
(0.87)\end{array}$ \\
\hline Total & $\begin{array}{c}2.49 \\
(0.86)\end{array}$ & $\begin{array}{c}2.41 \\
(0.46)\end{array}$ & $\begin{array}{l}2.69^{* *} \\
(0.67)\end{array}$ & $\begin{array}{c}2.11 \\
(0.49)\end{array}$ & $\begin{array}{c}2.56^{*} / * * \\
(0.45)\end{array}$ & $\begin{array}{c}2.30 \\
(0.39)\end{array}$ & $\begin{array}{c}2.16 \\
(0.45)\end{array}$ & $\begin{array}{l}2.53^{*} \\
(0.66)\end{array}$ & $\begin{array}{c}2.07 \\
(0.50)\end{array}$ & $\begin{array}{l}2.87^{*} \\
(0.57)\end{array}$ \\
\hline
\end{tabular}

Note: the mean of each dimension and indicator is presented in the table. The number in brackets refers to the standard deviation.

${ }^{*} p<.05,{ }^{* *} p<.001$.

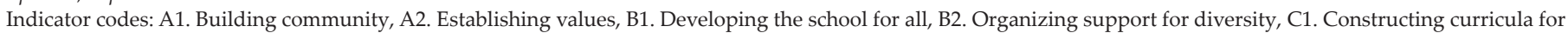
all, C2. Orchestrating learning. These codes for the sub-dimensions will be used from now on. 
of normality in the distribution of the sample in the four groups that made up this variable.

Finally, to get the effect size, Cohen's d was calculated through the $G^{*}$ Power program, and then it was interpreted in terms of small $(d=.20)$, medium $(d=.50)$ or large size $(d=.80)$. The ANOVA F-test was used to check whether the effect was small $(f=.10)$, medium $(f=.25)$ or large $(f=.40)$, and Kendall's w value for correlations, with similar values (small: $w=.10$; medium: $w$ $=.30$; large: $w=.50$ ) for the ranges (Cárdenas \& Arancibia, 2014).

\section{Results}

Table 2 shows the central tendency and dispersion values, differentiating by gender and academic year of the student, or academic year of teaching. The results of Student's T-test are included to show contrast in the variable of gender in families and teachers, and the ANOVA results for showing the contrast in the academic year variable. To complement that data, table 3 demonstrates the results of the Post-Hoc test which was used to identify in which groups the differences were located.

In relation to the families, the data in table 2 show a more positive evaluation of the inclusion in schools by fathers than by mothers, although this difference was not statistically significant $\left(t_{1356}=1.698, p=.092\right)$. Fathers gave significantly higher marks on Culture $\left(t_{134.1}=2.10, p=.034, p=0.34\right)$, its indicator building community $\left(t_{121.9}=2.34, p=.021, d=0.45\right)$, and Policy $\left(t_{136.4}=2.54, p=.013\right.$, $d=0.38)$, and its indicator organizing support for diversity $\left(t_{136.4}=\right.$ $2.51, p=.013, d=0.41)$. On the contrary, Practices was better rated by mothers, with a statistically significant result in its indicator constructing curricula for all $\left(t_{145.5}=-2.27, p=.024, d=0.37\right)$. The effect size was small in all cases $(d<0.50)$.

Similarly, a more positive evaluation was given by male teachers than by female (see table 2). Considering the significance values based on the non-assumption of equal variances (Levene's tests $<.001)$, a significant superiority in men's rating was obtained for the Index $\left(t_{74.98}=4.52, p<.001, d=0.98\right)$ and for all its dimensions; namely, Culture $\left(t_{71.16}=4.22, p<.001, d=0.92\right)$, Policy $\left(t_{44.23}=\right.$ $4.71, p<.001, d=1.02)$ and Practice $\left(t_{75.90}=3.76, p<.001, d=0.82\right)$, as well as for their indicators, with an associated probability of error that ranges from $1 \%$ to $4.3 \%$ and a large effect size $(d=1.02-0.55)$.

Statistically significant differences were also found in families in relation to the academic year variable (see table 2 and 3), with a medium $(f<.40)$ to large $(f>.40)$ effect size. Those differences referred to the general value of the Index $(F=14.10 ; p<.001, f=$ $.39)$ and to Culture $(F=4.66, p<.001, f=0.35)$ and its indicators (A1: $F=11.27, p<.001, f=0.36$; A2: $F=7.59, p=.001, f=0.30)$, as

Table 3.

Multiple comparisons: Post-Hoc Scheffé tests

\begin{tabular}{|c|c|c|c|c|c|c|c|c|c|c|c|}
\hline \multirow{3}{*}{ Variable } & \multirow{3}{*}{$\begin{array}{l}\text { Grade } \\
(\mathrm{I}-\mathrm{J})\end{array}$} & \multicolumn{5}{|c|}{ Families } & \multicolumn{5}{|c|}{ Teachers } \\
\hline & & \multirow{2}{*}{$\begin{array}{l}\text { Mean Diff. } \\
\text { (I-J) }\end{array}$} & \multirow{2}{*}{ S.E. } & \multirow{2}{*}{$d$} & \multicolumn{2}{|c|}{$\begin{array}{c}95 \% \text { Confidence } \\
\text { interval }\end{array}$} & \multirow{2}{*}{$\begin{array}{c}\text { Mean Diff. } \\
\text { (I-J) }\end{array}$} & \multirow{2}{*}{ S.E. } & \multirow{2}{*}{$d$} & \multicolumn{2}{|c|}{$\begin{array}{c}\text { 95\% Confidence } \\
\text { interval }\end{array}$} \\
\hline & & & & & $\begin{array}{l}\text { Lower } \\
\text { bound }\end{array}$ & $\begin{array}{l}\text { Upper } \\
\text { bound }\end{array}$ & & & & $\begin{array}{l}\text { Lower } \\
\text { bound }\end{array}$ & $\begin{array}{l}\text { Upper } \\
\text { bound }\end{array}$ \\
\hline \multirow{3}{*}{ Culture } & $1-2 / 3-4$ & $0.48^{*}$ & .12 & 0.34 & 0.17 & 0.78 & $0.48^{*}$ & .13 & 0.36 & 0.14 & 0.81 \\
\hline & $1-2 / 5-6$ & $0.51^{*}$ & .13 & 0.36 & 0.19 & 0.83 & & & & & \\
\hline & $3-4 / 5-6$ & & & & & & $-0.93^{*}$ & .24 & 0.56 & -1.53 & -0.32 \\
\hline \multirow{3}{*}{$A 1$} & $1-2 / 3-4$ & $0.63^{* *}$ & .15 & 0.37 & 0.26 & 1.01 & $0.52^{*}$ & .17 & 0.32 & 0.09 & 0.95 \\
\hline & $1-2 / 5-6$ & $0.59^{* *}$ & .16 & 0.34 & 0.21 & 0.98 & & & & & \\
\hline & $3-4 / 5-6$ & & & & & & $-1.16^{*}$ & .31 & 0.56 & -1.93 & -0.38 \\
\hline \multirow{3}{*}{$A 2$} & $1-2 / 3-4$ & $0.37^{*}$ & .13 & 0.27 & 0.06 & 0.68 & $0.43^{*}$ & .11 & 0.39 & 0.15 & 0.72 \\
\hline & $1-2 / 5-6$ & $0.46^{*}$ & .13 & 0.32 & 0.14 & 0.77 & & & & & \\
\hline & $3-4 / 5-6$ & & & & & & $-0.69^{*}$ & .21 & 0.51 & -1.21 & -0.18 \\
\hline \multirow{2}{*}{ Policies } & $1-2 / 5-6$ & $0.68^{* *}$ & .10 & 0.20 & 0.42 & 0.93 & $0.46^{*}$ & .15 & 0.23 & 0.09 & 0.83 \\
\hline & $3-4 / 5-6$ & $0.44^{* *}$ & .11 & 0.37 & 0.17 & 0.71 & $-0.93^{*}$ & .27 & 0.53 & -1.61 & -0.26 \\
\hline \multirow{3}{*}{ B1 } & $1-2 / 3-4$ & & & & & & $0.58^{* *}$ & .19 & 0.32 & 0.11 & 1.05 \\
\hline & $1-2 / 5-6$ & $0.67^{* *}$ & .12 & 0.50 & 0.38 & 0.97 & & & & & \\
\hline & $3-4 / 5-6$ & $0.43^{*}$ & .13 & 0.32 & 0.11 & 0.74 & $-1.12^{*}$ & .34 & 0.50 & -1.97 & -0.27 \\
\hline \multirow{3}{*}{ B2 } & $1-2 / 3-4$ & & & & & & $0.34^{*}$ & .12 & 0.29 & 0.03 & 0.65 \\
\hline & $1-2 / 5-6$ & $0.68^{* *}$ & .14 & 0.48 & 0.34 & 1.02 & & & & & \\
\hline & $3-4 / 5-6$ & $0.46^{* *}$ & .15 & 0.33 & 0.09 & 0.82 & $-0.74^{*}$ & .22 & 0.51 & -1.30 & -0.18 \\
\hline Practice & $1-2 / 3-4$ & & & & & & $0.47^{*}$ & .15 & 0.27 & 0.08 & 0.85 \\
\hline$C 2$ & $1-2 / 3-4$ & & & & & & $0.60^{*}$ & .21 & 0.32 & 0.09 & 1.12 \\
\hline \multirow{3}{*}{ Total } & $1-2 / 3-4$ & $0.26^{*}$ & .08 & 0.27 & 0.06 & 0.46 & $0.47^{*}$ & .14 & 0.35 & 0.12 & 0.82 \\
\hline & $1-2 / 5-6$ & $0.44^{* *}$ & .09 & 0.46 & 0.23 & 0.66 & & & & & \\
\hline & $3-4 / 5-6$ & & & & & & $-0.80^{*}$ & .25 & 0.48 & -1.43 & -0.17 \\
\hline
\end{tabular}

Note: ${ }^{*} p<.05 ;{ }^{* *} p<.001$. Only statistically significant results are included. 
Table 4 .

Descriptive statistics for the age: central tendency and dispersion values

\begin{tabular}{|c|c|c|c|c|c|c|}
\hline & \multicolumn{3}{|c|}{ Families (age) } & \multicolumn{3}{|c|}{ Teachers (age) } \\
\hline & $\begin{array}{c}<40 \\
(n=31)\end{array}$ & $\begin{array}{c}40-50 \\
(n=84)\end{array}$ & $\begin{array}{c}>50 \\
(n=42)\end{array}$ & $\begin{array}{c}<40 \\
(n=31)\end{array}$ & $\begin{array}{c}40-50 \\
(n=26)\end{array}$ & $\begin{array}{c}>50 \\
(n=28)\end{array}$ \\
\hline Culture & $2.55(0.69)$ & $2.52(0.66)$ & $2.29(0.75)$ & $2.55(0.66)$ & $2.45(0.65)$ & $2.36(0.62)$ \\
\hline$A 1$ & $2.63(0.89)$ & $2.47(0.81)$ & $2.19(0.87)$ & $2.52(0.79)$ & $2.40(0.87)$ & $2.27(0.76)$ \\
\hline$A 2$ & $2.51(0.65)$ & $2.55(0.66)$ & $2.35(0.77)$ & $2.59(0.57)$ & $0.49(0.53)$ & $2.45(0.52)$ \\
\hline Policies & $2.50(0.62)$ & $2.37(0.56)$ & $2.28(0.61)$ & $2.45(0.62)$ & $2.30(0.72)$ & $2.28(0.75)$ \\
\hline B1 & $2.53(0.68)$ & $2.31(0.65)$ & $2.25(0.68)$ & $2.61(0.82)$ & $2.38(0.97)$ & $2.26(0.83)$ \\
\hline B2 & $2.45(0.78)$ & $2.44(0.75)$ & $2.32(0.76)$ & $2.29(0.51)$ & $2.22(0.51)$ & $2.29(0.69)$ \\
\hline Practice & $2.19(0.52)$ & $2.21(0.59)$ & $2.30(0.49)$ & $2.63(0.70)^{*}$ & $0.32(0.66)$ & $2.25(0.67)$ \\
\hline $\mathrm{Cl}$ & $2.30(0.63)$ & $2.25(0.73)$ & $2.34(0.66)$ & $2.60(0.69)$ & $2.37(0.56)$ & $3.34(0.64)$ \\
\hline $\mathrm{C} 2$ & $2.09(0.58)$ & $2.17(0.72)$ & $2.25(0.60)$ & $2.68(0.89)^{*}$ & $2.25(0.97)$ & $2.15(0.85)$ \\
\hline INDEX & $2.43(0.46)$ & $2.38(0.46)$ & $2.29(0.49)$ & $2.53(0.63)$ & $2.35(0.66)$ & $2.30(0.66)$ \\
\hline
\end{tabular}

Note: the mean of each dimension and indicator is presented in the table. The number in brackets refers to the standard deviation.

${ }^{*} p<.05,{ }^{* *} p<.001$.

well as to Policy $(F=5.95, p<.001, f=0.47)$ and its indicators (B1: $F=15.93, p<.001, f=0.41$; B2: $F=12.14, p<.001, f=0.37)$, but not for Practices $(F=0.445 ; p<.642)$ or its indicators.

A Post-Hoc test (see table 3) showed that families whose children were in the first academic years (1st-2nd) gave a significantly more positive evaluation of Inclusion in schools; specifically, Culture received a better mark in grades 3-6 (including the differences between Building community and Establishing values), and Policy compared to those in 5th-6th grade (only in Organizing support for diversity). That indicator was also statistically higher in families whose children were in 3rd-4th academic year versus those in grades 5-6.

As for the teachers, the mid-term courses (3rd-4th) got the most negative evaluation of inclusion, whereas the 5 th grade received the best rates. The ANOVA test confirmed that those differences were statistically significant, with a large effect size $(f<.40)$ in the Index $(F=7.91, p=.001, f=0.40)$ and in some of its dimensions: Culture $(F=9.94, p<.001, f=0.44)$ and its indicators $(\mathrm{A} 1: F=8.72, p<.001, f=0.42 ; \mathrm{A} 2: F=9.65, p=.001, f=0.43)$, and Policy $(F=8.11, p=.001, f=0.40)$, and medium effect size in Policy's indicators (B1: $F=7.55, p=.001, f=0.39$; B2: $F=6.92, p=.002$, $f=0.38)$ and in Practice $(F=4.70, p=.012, f=0.26)$ and one of its indicators ( $\mathrm{C} 2: F=4.74, p=.011, f=0.32)$.

As shown table 3, teachers from the first academic years (1st2nd) gave a significantly more positive evaluation of the Index (except for Constructing curricula for all in Practice) than those teaching in grades 3-4. Similarly, the rates from grade 5 teachers were significantly higher in all dimensions and indicators than those from 3rd-4th-grade teachers (except for the above-mentioned indicator of Practice).

Studying the influence of the age in parents' and teachers' perception (see table 4 ) revealed the presence of differences where the highest evaluations of inclusion were given by the youngest respondents, meanwhile lower scores were obtained as the age of participants increased.

No statistically significant differences were found in case of families, although further analysis demonstrated a significant, negative, and weak correlation between the parents' age and the Culture $(r=-.161, p=.044, w=0.40)$ and Building community $(r=$ $-.186, p=.020, w=0.43)$.
As for teachers, the Kruskal-Wallis $\mathrm{H}$ test, used given the absence of assumption of normality and homogeneity of variances, revealed the presence of statistically significant differences in Practices $\left(\chi_{2}^{2}=6.08, p=.048\right)$ and its indicator Orchestrating learning $\left(\chi_{2}^{2}=6.16, p=.046\right)$. The Mann-Whitney $U$ test confirmed that teachers under the age of 40 evaluated significantly more positively the Practice in their schools and its indicator Orchestrating learning $(\mathrm{U}=283.00, \mathrm{Z}=-2.30, p=.021, d=0.48)$ than those over $50(\mathrm{U}=275.00, Z=-2.42, p=.016, d=0.52)$. No significant correlations were found out between age and teachers' perception of inclusion.

As shown in table 5, no statistically significant differences were found in families whose children presented (or not) difficulties/disabilities concerning inclusion in schools $(p=.723)$, nor in their dimensions: Culture $(p=.592)$, Policy $(p=.363)$ and Practice $(p=.340)$.

With respect to the teachers' function at school (see table 5), an ANOVA test confirmed the presence of statistically significant differences $(p<.05)$. This means that the counselors' ratings stood out over support teachers' ratings on Culture $(p=.038, f=0.46)$ and its indicator Building community $(p=.022, f=0.49)$, as well as the indicator Orchestrating learning in Practice $(p=.014, f=0.52)$. The tutors valued more positively the indicator Establishing values in Culture, as opposed to support teachers $(p=.022, f=0.30)$, just as Policy $(p=.038, f=0.34)$ and its two indicators: Developing schools for all ( $p=.034, f=0.33)$ and Organizing supports for diversity $(p=.045 . f=0.31)$ and all in all, in the Index $(p=.049, f=0.31)$. The management team also rated higher than the support teachers on Policy ( $p=.016, f=0.48)$ and its two indicators (Constructing curricula for all: $p=.043, f=0.43$ and Orchestrating learning: $p=$ $.010, f=0.51)$.

Finally, the contrast between the families' and teachers' ratings of the Index, through the Student's T-test for related samples (see table 6) showed a high degree of agreement, with no statistically significant differences. There were differences in some dimensions and indicators, with a small effect size $(d<0.40)$ in favor of families in Culture $\left(t_{84}=2.54, p=.013\right)$ and, especially, in the indicator Building community $\left(t_{84}=3.04, p=.003\right)$, just as in the indicator Organizing supports for diversity in Policy $\left(t_{84}=2.05, p=\right.$ $.043)$. Teachers rated significantly more positively Practice $\left(t_{84}=\right.$ $-2.20, p=.031)$. 
Table 5.

Descriptive statistics of children's learning difficulties and teachers' function: central tendency and dispersion values

\begin{tabular}{|c|c|c|c|c|c|c|}
\cline { 2 - 6 } \multicolumn{1}{c|}{} & \multicolumn{2}{c|}{ Families (child's difficulties) } & \multicolumn{3}{c|}{ Teachers' function } \\
\cline { 2 - 6 } \multicolumn{1}{c|}{} & $\begin{array}{c}\text { Yes } \\
(n=56)\end{array}$ & $\begin{array}{c}\text { No } \\
n=102)\end{array}$ & $\begin{array}{c}\text { Tutor } \\
(\boldsymbol{n}=\mathbf{4 1})\end{array}$ & $\begin{array}{c}\text { Support } \\
(\boldsymbol{n}=\mathbf{3 2})\end{array}$ & $\begin{array}{c}\text { Management team } \\
(\boldsymbol{n}=\mathbf{8})\end{array}$ & $\begin{array}{c}\text { Counsellor } \\
(\boldsymbol{n}=\mathbf{4})\end{array}$ \\
\hline Culture & $2.42(0.72)$ & $2.49(0.68)$ & $2.55(0.63)$ & $2.16(0.46)$ & $2.81(0.90)$ & $3.10(0.36)^{*}$ \\
\hline A1 & $2.34(0.89)$ & $2.48(0.83)$ & $2.47(0.80)$ & $2.07(0.59)$ & $2.90(1.09)$ & $3.33(0.33)^{*}$ \\
\hline A2 & $2.48(0.73)$ & $2.49(0.67)$ & $2.63(0.53)^{*}$ & $2.26(0.39)$ & $2.73(0.76)$ & $2.88(0.39)$ \\
\hline Policy & $2.31(0.60)$ & $2.40(0.58)$ & $2.47(0.67)^{*}$ & $2.00(0.57)$ & $2.83(0.81)^{*}$ & $2.89(0.28)$ \\
\hline B1 & $2.28(0.63)$ & $2.37(0.68)$ & $2.58(0.87)^{*}$ & $2.00(0.67)$ & $2.94(1.11)^{*}$ & $3.19(0.22)$ \\
\hline B2 & $2.35(0.81)$ & $2.44(0.73)$ & $2.36(0.55)^{*}$ & $2.00(0.51)$ & $2.72(0.55)^{*}$ & $2.59(0.36)$ \\
\hline Practice & $2.29(0.55)$ & $2.20(0.55)$ & $2.50(0.78)$ & $2.17(0.47)$ & $2.56(0.77)$ & $3.08(0.39)$ \\
\hline C1 & $2.42(0.69)$ & $2.21(0.68)$ & $2.48(0.77)$ & $2.34(0.44)$ & $2.53(0.70)$ & $2.75(0.44)$ \\
\hline C2 & $2.15(0.64)$ & $2.18(0.67)$ & $2.54(0.96)$ & $1.97(0.70)$ & $2.59(1.04)$ & $3.5(0.35)^{*}$ \\
\hline INDEX & $2.35(0.49)$ & $2.37(0.46)$ & $2.50(0.66)$ & $2.10(0.49)$ & $2.76(0.81)$ & $3.01(0.28)$ \\
\hline
\end{tabular}

Note: the mean of each dimension and indicator is presented in the table. The number in brackets refers to the standard deviation.

${ }^{*} p<.05,{ }^{* *} p<.001$.

Table 6.

Statistics and correlations between paired samples

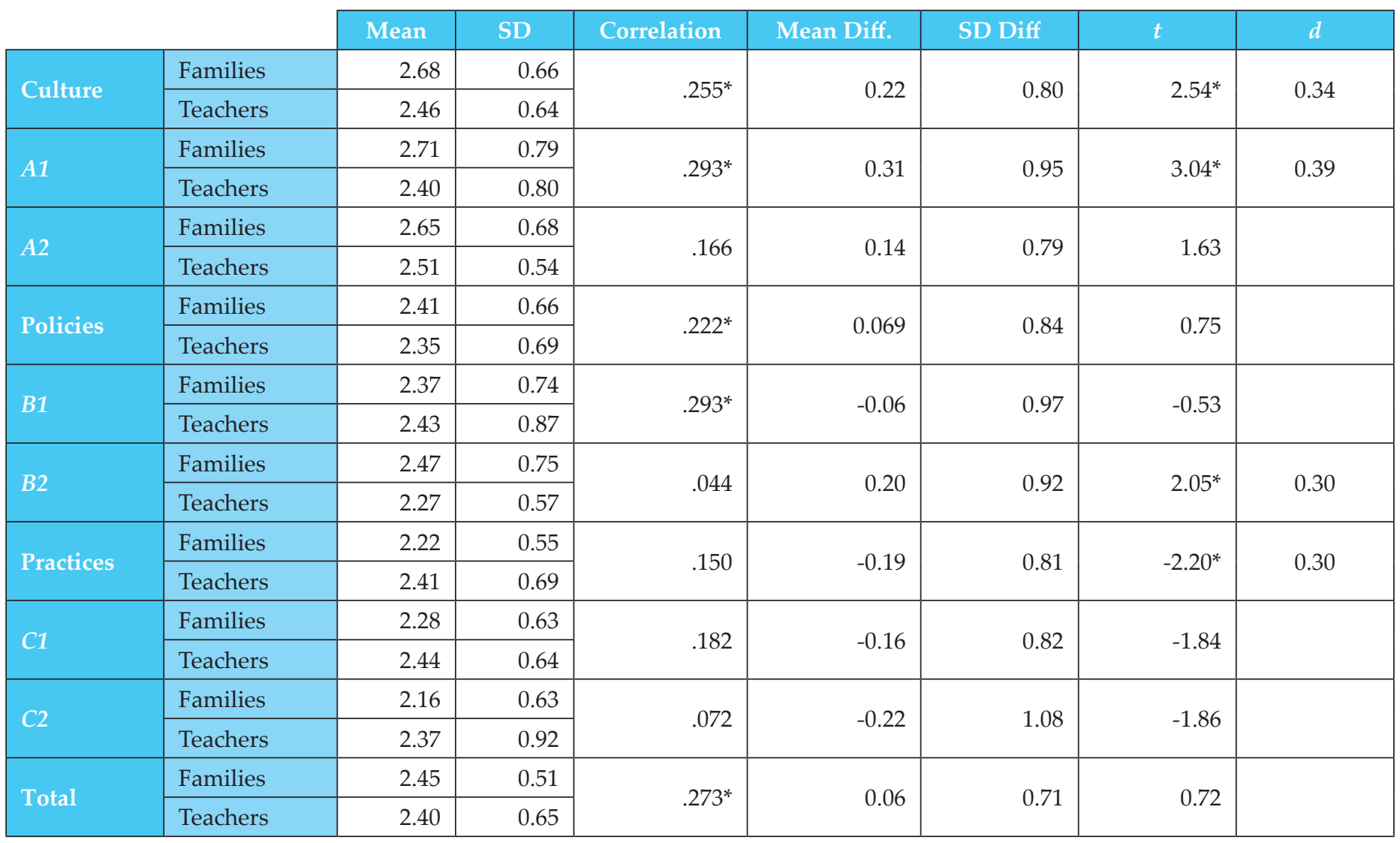

\section{Discussion and conclusions}

inclusion in schools is a reality supported and favorably assessed by two key agents in those institutions. Families and teachers share a moderately positive perception of the inclusion of their children/students. This outcome has enabled a closer look at the inclusive approach (Arnaiz \& Azorín, 2014) which reflects the effectiveness of the scholar measures in the promotion of the inclusive values beyond the school gates, getting closer to the sought-after teachers-families link (Malone, 2020).

Families positively highlighted the inclusive cultures configuration in their children's schools and, above all, in the building up of a community, just as the inclusive policies in relation to the way of organizing the support for diversity, as it was stated in previous research (Paseka \& Schwab, 2020). The best evaluation given to Practices by the teachers seems a far cry from reality, as 
such a response could simply be guided by "political correctness" rather than the natural views of those individuals (Ramírez \& Muñoz, 2013, p. 217).

The more positive evaluation of inclusion by men than by women could be, in case of teachers, since in Spain teaching in the first levels of education has always been considered a rather female profession, and schools quite feminized environments (Ruan \& Zheng, 2019). In choosing the teaching profession, the vocational factors often have smaller weight for women than social and economic factors (shorter training time and lower cost of studies, compared to other degrees). The incorporation of male teachers in primary education is very recent, with a strong vocational character. Even so, previous studies provide conflicting results, finding these differences in attitudes and knowledge towards inclusive education in favor of women, in Secondary Education (Pegalajar \& Colmenero, 2017), but not when studying together early childhood, primary, and secondary education (Garzón et al., 2015).

As far as families are concerned, the discrepancies between the higher value placed on the creation of culture and the development of inclusive policies by fathers, as opposed to the more positive perception of practices by mothers, could be explained in light of the role traditionally played by each parent in their involvement with schools, with a bigger presence of mothers in everything concerning their children's activities, as continues to be evident in recent studies (Ruan \& Zheng, 2019). This may be why the mothers experience first-hand how inclusion practices are implemented in schools (Llorens, 2012).

Families' perception of inclusion according to the grade and age may be revealing a new reality: the lower participation of the families as the children are growing up. This may be interpreted not as a misestimation of inclusion, but as a dwindling presence (hence, less knowledge) in the school's space and internal dynamics. This would lead to propose as a priority to increase the involvement of families in all stages (Mateus et al., 2017; Paseka \& Schwab, 2020) given its effectiveness in a better development of children (Yotyodying \& Wild, 2019).

Similarly, a better evaluation of Practice by younger teachers can be justified by a greater awareness of the need to educate in inclusive values (Booth \& Ainscow, 2015), and a better predisposition of the new generations (Materechera, 2020), who receive university training that incorporates specific subjects on Inclusive Education and specialized training Masters. Even so, this data requires further examination since, as Pegalajar \& Colmenero (2017) state, although there are studies that confirm higher attitudes and training needs in teachers with less professional background, others reject the presence of a relationship between teaching attitudes and years of experience.

The lowest evaluation of inclusion among support teachers, as opposed to counselors, tutors, and even teaching staff, especially in Policies, could be justified considering the study by Verger, Chover and Roselló (2020) who confirm that the support teachers represent an isolated agent in schools, and still in many schools, their work is carried out in specific classrooms, thus maintaining "an educational vision closer to integration than to inclusion" (p. 175). Maybe they have a closer insight into this reality and their opinions are more critical regarding how much support there is and how it is distributed among functionally diverse students (Mateus et al., 2017; Verger et al., 2020), and the possibilities of schools to carry out the actions to convert the school into a school for all. Facing this situation, teaching and management teams are called upon to assume greater involvement in the challenge of inclusion (Arnaiz \& Azorín, 2014) and a modification of the role of support teachers, which undoubtedly involves achieving a real transition from integration to inclusion (Soldevilla et al., 2017; Verger et al., 2020).

Definitely, the Index for Inclusion enables to explore the reality of each school giving voice to all its members by promoting joint reflection, and make possible to paint a larger picture of inclusion, centered on the perceptions of families and teachers, instead of the restrictive perspective focused on students with SEN. Although the results seem to point in a good direction, there are undeniable weaknesses and barriers to inclusion. Culture, policies, and practice cannot be separated, whether it is intended to deal with a global conception of an inclusive school. This is a first step and, although there is still a long way to go, the Index for Inclusion is a good road map.

\section{Reference list}

Ainscow, M. (2002). Rutas para el desarrollo de prácticas inclusivas en los sistemas educativos. Revista de Educación, 327, 6982. https://sede.educacion.gob.es/publiventa/detalle.action?cod $=10520$

Ainscow, M. \& Messiou, K. (2018). Engaging with the views of students to promote inclusion in education. Journal of Educational Change, 19, 1-17. https://doi.org/10.1007/s10833-017-9312-1

Arnaiz, P. \& Azorín, C. (2014). Autoevaluación docente para la mejora de los procesos educativos en escuelas que caminan hacia la inclusión. Revista Colombiana de Educación, 67, 227-245. http://doi.org/ 10.17227/0120391.67rce227.245

Azorín, C. \& Ainscow, M. (2020). Guiding schools on their journey towards inclusion. International Journal of Inclusive Education, 24(1), 58-76. https://doi.org/10.1080/13603116.2018.14 50900

Booth, T., \& Ainscow, M. (2015). Guía para la evaluación y mejora de la educación inclusiva. Desarrollando el aprendizaje y la participación en las escuelas (Trad. G. Echeita, Y. Muñoz, C. Simón, \& M. Sandoval). Madrid: OEI. (Adapted from 3a ed.; original work published 2011).

Braunsteiner, M.L. \& Mariano-Lapidus, S. (2014). A perspective of inclusion: Challenges for the future. Global Education Review, 1(1). 32-43. Retrieved from https://files.eric.ed.gov/fulltext/ EJ1055217.pdf

Cárdenas, M. \& Arancibia, H. (2014). Potencia estadística y cálculo del tamaño del efecto en $\mathrm{G}^{*}$ Power. Salud \& Sociedad, 5(2), 210224. http://doi.org/10.22199/S07187475.2014.0002.00006

Cardona-Molto, M.C., Ticha, R. \& Abery, B.H. (2020). The Spanish version of the teacher efficacy for inclusive practice (TEIP) scale: Adaptation and psychometric properties. European Journal of Educational Research, 9(2), 809-823. https://doi.org/10.12973/ eu-jer.9.2.809

Castillo, P., Miranda, C., Norambuena, I., \& Galloso, E. (2020). Validación de los instrumentos basados en el Index for Inclusion para el contexto educativo chileno. Revista de Estudios y Experiencias en Educación, 19(41), 17-27. http://dx.doi.org/10.21703/ rexe.20201941castillo1

Cenci, A., Ferreira, M., Fuhro, D., Damiani, M.F. \& Engeströme, Y. (2020). The contradictions within inclusion in Brazil. Learning, Culture and Social Interaction, 24, 1-14. https://doi.org/10.1016/j. lcsi.2019.100375

Collet-Sabé, J. (2020). Les relacions entre l'escola i les famílies des d'una perspectiva democràtica: eixos d'anàlisi i propostes per a l'equitat. Educar, 56(1), 241-258. https://doi.org/10.5565/rev/ educar.1012

Collet-Sabé, J., Besala, X., \& Tort, A. (2014). Escuelas, familias y resultados académicos. Nuevo modelo de análisis de las relaciones entre docentes y progenitores para el éxito de todo 
el alumnado. Profesorado, 18(2), 7-33. https://doaj.org/article/ 0353bb33351342c896aacca8d20c24a9

Crisol, E. (2019). Hacia una educación inclusiva para todos. Nuevas contribuciones. Profesorado, 23(1), 1-9. https://doi. org/10.30827/profesorado.v23i1.9141

Egido, I., \& Bertrán, M. (2016). Prácticas de colaboración familia-escuela en centros de éxito en entornos desfavorecidos. Pedagogía Social. Revista Interuniversitaria, 29, 97-110. http://doi. org/ 10.7179/PSRI_2017.29.07

Fernández-Archilla, J.A., Álvarez, J.F., Aguilar-Parra, J.M., Trigueros, R., Alonso-López, I.D., \& Echeita, G. (2020). Validation of the Index for Inclusion Questionnaire for Compulsory Secondary Education Students. Sustainability, 12(6), 2169; https://doi. org/10.3390/su12062169

Garzón, P., Clavo, M. I., \& Orgaz, M.B. (2016). Inclusión educativa. Actitudes y estrategias del profesorado. Revista Española de Discapacidad, 4(2): 25-45. https://doi.org/10.5569/23405104.04.02.02

Hedegaard-Soerensen, L. \& Grumloese, S.P. (2020). Exclusion: the downside of neoliberal education policy. International Journal of Inclusive Education, 24(6), 631-644. https://doi.org/10.1080/1 3603116.2018.1478002

Hernández, R., Fernández, F., Baptista, P., Méndez, S. \& Mendoza, C.P. (2015). Metodología de la investigación (6th ed). México: McGraw Hill.

Llorens, A.J. (2012). Actitud ante la inclusión de niños y niñas con necesidades educativas especiales Consideraciones de padres, madres y profesionales de la educación. Fòrum de Recerca, 17, 209-217. http://dx.doi.org/10.6035/ForumRecerca.2012.17.13

Malone, H.J. (2020). Community schools: bridging educational change through partnership. Journal of Educational Change, 21, 87-497. https://doi.org/10.1007/s10833-020-09375-2

Materechera, E.K. (2020). Inclusive education: why it poses a dilemma to some teachers. International Journal of Inclusive Education, 24(7), 771-786. https://doi.org/10.1080/13603116.2018. 1492640

Mateus, L.E., Vallejo, D.M., Obando, D. \& Fonseca, L. (2017). Percepción de las prácticas y cultura inclusiva en una comunidad escolar. Avances en Psicología Latinoamericana, 35(1), 177-191. http://dx.doi.org/10.12804/revistas.urosario.edu.co/apl/a.4854

Messiou, K. \& Ainscow, M. (2020). Inclusive Inquiry: Student-teacher dialogue as a means of promoting inclusion in schools. British Educational Research Journal, 46(3), 670-687. https://doi. org/10.1002/berj.3602

Ministerio de Educación y Formación Profesional (2019). Sistema estatal de indicadores de la educación 2019. Retrieved from http:// www.educacionyfp.gob.es/dam/jcr:627dc544-8413-4df1-ae46558237bf6829/seie-2019.pdf
Nes, K. (2009). The Role of the Index for Inclusion in supporting school development in Norway: a comparative perspective. Research in Comparative and International Education, 4(3), 305320. http://dx.doi.org/10.2304/rcie.2009.4.3.305

Paseka, A. \& Schwab, S. (2020). Parents' attitudes towards inclusive education and their perceptions of inclusive teaching practices and resources. European Journal of Special Needs Education, 35(2), 254-272. https://doi.org/10.1080/08856257.2019.1665232

Pegalajar, M.C., \& Colmenero, M.J. (2017). Actitudes y formación docente hacia la inclusión en Educación Secundaria Obligatoria. Revista Electrónica de Investigación Educativa, 19(1), 84-97. https://doi.org/10.24320/redie.2017.19.1.765

Ramírez, A. \& Muñoz, M.C. (2012). Prácticas inclusivas de los docentes en la convivencia escolar y en la organización y funcionamiento de los centros de educación primaria de la zona norte de Córdoba. Revista de Investigación Educativa, 30(1), $197-$ 222. http://doi.org/ 10.6018/rie.30.1.116241

Real Decreto Legislativo 1/2013, de 29 de noviembre, por el que se aprueba el texto refundido de la Ley General de Derechos de las personas con discapacidad y de su inclusión social. BOE núm. 289, de 3 de diciembre, 1-44.

Ruan, X. \& Zheng, X. (2019). The rhetoric and the reality: Exploring the dynamics of professional agency in the identity commitment of a Chinese female teacher. Learning, Culture and Social Interaction, 21, 348-361. https://doi.org/10.1016/j. lcsi.2019.04.008

Senge, P.M. (1989). The Fifth Discipline: The art and practice of the learning organization. London: Century.

Simón, C. \& Barrios, A. (2019). Las familias en el corazón de la educación inclusiva. Aula Abierta, 48(1), 51-58. https://doi. org/10.17811/rifie.48.1.2019.51-58

Soldevilla, J., Naranjo, M. \& Muntaner, J.J. (2017). Inclusive practices: the role of the support teacher. Aula Abierta, 46(2), 49-56. https://doi.org/10.17811/rifie.46.2017.49-56

Valanzuela, C., \& Sales, A. (2016). Los efectos de la participación familiar dentro del aula ordinaria. Revista Nacional e Internacional de Educación Inclusiva, 9(2), 71-86 https://revistaeducacioninclusiva.es/index.php/REI/article/view/288

Verger, S., Chover, L. \& Rosselló, M.R. (2020). La contribución del/de la auxiliar técnico educativo (ATE) para el desarrollo de una plena inclusión. Aula Abierta, 49(2), 171-176. https://doi. org/10.17811/rifie.49.2.2020.171-176

Yotyodying, S. \& Wild, E. (2019). Effective family-school communication for students with learning disabilities: Associations with parental involvement at home and school. Learning, Culture and Social Interaction, 22, 300-317. https://doi.org/10.1016/j. lcsi.2019.100317 
